\title{
POLA KOMUNIKASI ANTAR PRIBADI ORANG TUA DAN ANAK DALAM MENINGKATKAN KEMANDIRIAN ANAK USIA 4-6 TAHUN
}

Andhi Ardhian Jaelany, Veny Purba

Universitas Adhirajasa Reswara Sanjaya (ARS)

E-mail:kandhi17@gmail.com

\begin{abstract}
This research was conducted to explain the patterns of interpersonal communication between parents and children in increasing the independence of children in Waladun Sholeh Kindergarten. This study used a qualitative method with the research subjects being parents and teachers at Waladun Sholeh Kindergarten. Object of research is the process of parental interaction in developing children's independence. Data collected through indepth interviews and analysis documents. The research data that has been collected is analyzed qualitatively and data analysis is carried out at all times the data collection at the research location on an ongoing basis. The results of the study that the communication process that exists between parents and children is effective. This is caused by the interaction that exists between parents and children continuously in daily activities.
\end{abstract}


Keywords : Communication Patterns, Early Childhood,
Independence.

\begin{abstract}
Abstrak
Penelitian ini dilakukan untuk menjelaskan pola komunikasi antarpribadi orangtua dan anak dalam meningkatkan kemandirian anak di TK Waladun Sholeh. Penelitian ini menggunakan metode kualitatif dengan subjek penelitiannya adalah orangtua dan guru di TK Waladun Sholeh. Objek penelitian adalah proses interaksi orangtua dalam mengembangkan kemandirian anak. Data dikumpulkan melalui wawancara mendalam dan dokumen analisis. Hasil penelitian bahwa proses komunikasi yg terjalin antara orangtua \& anak efektif. Hal ini ditimbulkan karena adanya hubungan yg terjalin antara orangtua dan anak secara terus menerus dalam kegiatan sehari-hari.
\end{abstract}

Kata Kunci : Pola Komunikasi, Anak Usia Dini, Kemandirian.

\title{
Pendahuluan
}

Kemandirian anak usia dini merupakan salah satu hal yang penting dalam suatu proses pembelajaran. Kemandirian belajar dibutuhkan supaya mereka mempunyai tanggung jawab dalam mengatur dan mendisplinkan dirinya. Latihan kemandirian yang di berikan kepada anak harus di sesuaikan dengan usia anak usia dini. Dengan pola perilaku mandiri atau tidak mandiri akan menjadi dasar pembentukan perilaku di masa datang. Peran orangtua memiliki peranan yang 
sangat penting bagi perkembangan kemandirian anak sejak dini sebab kemandirian anak sudah bisa di ajarkan pada anak sejak usia 2 tahun

Pembentukan kemandirian dipengaruhi oleh keluarga dan lingkungan, namun faktor yang paling berpengaruh adalah keluarga khususnya peranan orang tua. Orang tua dapat mendorong anak untuk mandiri dengan mengajar dan membimbing mereka melakukan rutinitas kecil sehari-hari. Ibu berperan menjadi orang tua dipercaya mempunyai keterbatasan pada proses pembentukan kemandirian anak. Adanya figur ayah pada keluarga menciptakan anak sebagai disiplin , mempunyai rasa percaya diri. Orang tua yang tidak kontinyu menjalankan disiplinnya (Retnowati, 2008) (Frankl,1972). Di satu sisi diyakini bahwa kedisiplinan, rasa percaya diri adalah dasar terbentuknya perilaku mandirian anak.

Komunikasi salah satu factor yang perlu diperhatikan orang tua menginginkan anaknya mandiri. Melalui komunikasi, orang tua dapat membangun kemandirian anak. Sikap, perilaku mandiri dapat berkembang baik melalui latihan, dorongan orang tua yang disampaikan melalui komunikasi. Komunikasi interpersonal menjadi sebuah proses komunikasi antara komunikan dan komunikator yang ditandai menggunakan terwujudnya saling pengertian, kesenangan, saling mempengaruhi, interaksi sosial yang baik, pula adanya tindakan nyata menjadi umpan-balik (Azeharie \& Khotimah, 2015) (Deddy Mulyana,2008:81).

Mendidik anak supaya mandiri adalah tugas setiap orangtua, dan sebagai tujuan penting pada membesarkan anak. Kemandirian merupakan perilaku yang penting dipelajari anak semenjak dini. Kemandirian berarti kemampuan seseorang untuk melakukan, memikirkan dan merasakan sesuatu, untuk mengatasi masalah, bersaing, mengerjakan tugas, dan mengambil keputusan dengan tingkat kepercayaan diri yang tinggi, bertanggung jawab, serta tidak bergantung pada bantuan orang lain. Pengaruh dan arahan sikap orang Iain lebih kecil dibanding dengan dorongan yang berasal dari dalam dirlnya. Meski juga disadari, bahwa dalam aktivitasnya seseorang tidak akan pernah bebas secara total dari ketergantungan orang lain. 
Proses menuju kemandirian bukan proses yang sekali jadi. Kemandirian merupakan proses panjang yang harus dialami oleh seseorang. Beranalogi demikian, semakin awal sikap ini dimiliki oleh seseorang akan semakin baik, mengingat dalam setiap fase kehidupannya seseorang akan membuat sejarah bagi dirinya, dan tentu saja hal tersebut harus dilakukannya secara cermat dan hati-hati. Usia dini mempunyai peran yang penting bagi pembentukan kemandirian anak. Adanya campur tangan dominan dari orang lain dalam satu tahap kehidupan anak. Untuk Itu menjadi keharusan bagi para orangtua, atau pendidik untuk sejak dini mempersiapkan anak berperilaku mandiri.

Mengingat kemandirian akan banyak memberikan dampak yang positif bagi perkembangan individu, maka lebih baik kemandirian dibimbing pada saat anak berusia sedini mungkin sesuai kemampuannya. Seperti telah diakui segala sesuatu yang dapat diusahakan sejak anak usia dini dapat diterapkan dan akan semakin berkembang menuju kesempurnaan. Pendidikan anak usia dini mengacu pada pendidikan yang diberikan kepada anak usia $0-6$ tahun atau sampai dengan usia 8 tahun. Sebenarnya, saat anak masih ada di dalam kandungan, pendidikan secara tidak disadari telah diberikan oleh sang ibu diantaranya berwujud pembiasaan, kedisiplinan, kebersihan, keteraturan, kesehatan dan gizi, kenyamanan juga kesabaran. Kecerdasan intelektual anak sudah $80 \%$ berkembang hingga anak usia 8 tahun (Putra \& Jannah, 2013) ( Santoso, 2007).

Komunikasi antara orangtua dan anak memiliki peranan penting supaya anak dapat meningkatkan kemandiriannya dan harus di ajarkan sejak dini. Komunikasi dapat dilakukan dengan bahasa verbal dan non verbal yang dapat dimengerti oleh kedua belah pihak. Bahasa verbal yaitu komunikasi yang sering kita lakukan sehari-hari dengan ucapan dan perkataan, bahasa non-verbal merupakan bahasa tubuh atau tindakan yang kita lakukan sehari-hari, misalnya seperti memukul, mengangguk, dan lain lainnya. Komunikasi terjadi dimana saja seperti dirumah, sekolah, kantor serta di semua tempat yang terjadi sosialisasi termasuk komunikasi dengan orangtua (Bala et al., 2015). Effendy (2002) mendefinisikan komunikasi sebagai sebuah proses penyampaian pesan oleh seorang kepada orang lain untuk memberitahu, mengubah sikap, pendapat, atau perilaku, baik secara lisan (langsung) ataupun tidak langsung (melalui media). 
Contohnya cara berkomunikasi kita dengan orang yang lebih tua tentu berbeda dengan teman sebaya atau orang yang lebih muda dari kita. Terlebih lagi komunikasi dalam keluarga yang selalu terjalin antara orangtua dan anak. Perlu mendapatkan bimbingan dan arahan disertai informasi yang benar.

\section{Metode Penelitian}

Penelitian ini menggunakan metode penelitian kualitatif deskriptif. Penelitian ini berbentuk deskriptif sebab tujuan penelitian ini menggambarkan atau mendeskripsikan Pola komunikasi antarpribadi orangtua dan anak dalam meningkatkan kemandirian anak usia 4-6 tahun. Subjek penelitian ini yaitu 2 kriteria orangtua dari anak di TK Waladun Sholeh dan 1 guru. Adapun objek yang dikaji dalam penelitian ini ialah proses interaksi orangtua dalam mengembangkan kemandirian anak melalui interaksi. Dengan pendekatan studi kasus, peneliti berusaha menggambarkan segala sesuatu yang terjadi dilapangan, untuk kemudahan analisa demi mencapai tujuan penelitian.

Subjek Penelitian ini yaitu 3 orangtua dari anaknya yang akan menjadi fokus penelitian di TK Waladun Sholeh Bekasi. Karena pada penelitian ini berfokus kepada interkasi yang terjadi antara orantua dan anak. Adapun kriteria dari subjek penelitian sebagai berikut :

a. Orang tua yang anaknya kurang mandiri dalam melakukan aktifitas kecil sehari-harinya, dengan artian selalu bergantung kepada orang tuanya.

b. Orangtua yang anaknya sangat mandiri dalam melakukan aktifitas kecil sehari-harinya, memiliki inisiatif tanpa harus bergantung pada orangtuanya.

c. Guru dari TK Waladun Sholeh, sebagai data pendukung.

Teknik analisis berupa pengambilan data melalui dokumen tertulis maupun secara online dari tempat penelitian. Gambaran data hasil penelitian maka dapat di lakukan prosedur sebagai berikut. Reduksi data merupakan bentuk analisis untuk mempertajam, memfokuskan, membuang, serta mengatur data sedemikian rupa sabagai akibatnya akhir dari kesimpulan yang di tarik dan diverifikasi. Lalu menggunakan Display Data praktikan pengorganisasian atau kompresi keterangan 
yang memungkingkan penarikan konklusi dan tindakan. Serta penarikan kesimpulan yang diharapkan adalah temuan baru yang sebelumnya belum pernah ada atau berupa gambaran suatu obyek yang sebelumnya masih remang-remang atau gelap sehingga setelah diteliti menjadi jelas.

\section{Hasil dan Pembahasan}

Penelitian ini dilakukan di TK Waladun Sholeh yang beralamat Gg. Doyok No.24, RT.004/RW.024, Kayuringin Jaya, Kecamatan Bekasi Selatan, Kota Bekasi, Jawa Barat. Pada 2 orang tua dan 1 guru, responden tersebut sudah memenuhi kriteria yang peniliti butuhkan. Penelitian akan membahas mengenai Pola Komunikasi Antarpribadi Orangtua dan Anak dengan 2 pertanyaan sebagai berikut:

\section{Proses Komunikasi Orangtua Dengan Anak Dalam Membentuk Kemandirian Anak Sejak Usia Dini}

Orang tua perlu menyadari pentingnya membangun kemandirian anak semenjak dini. Bahwa menjadi orang tua, kita tidak mampu hidup selamanya buat menjaga anak. Ada masanya seseorang anak wajib hidup sendiri tanpa orang tua. Di sini orang tua adalah membimbing kemandirian anak yang pertama kali pada hidupnya. Selalu melatih, mencontohkan kemandirian. Mengajari anak buat melakukan aktivitas sehari-hari dengan mandiri, misalnya mengajak anak buat mencuci piringnya setelah makan, membersihkan tempat tidur dan mengurus dirinya sendiri (misalnya mandi \& menggosok gigi). Tetapi harus tetap dalam pengawasan orangtua. Keharusan bagi anak buat berlatih mandiri tanpa didampingi orang tua. Sebagai orang tua, kita bisa melatih anak berangkat sekolah dengan teman-temannya tanpa diantar jemput setiap hari. Hal ini bisa melatihnya supaya bisa mandiri. ketika dituntut buat sekolah lebih tinggi dan jauh dari orang tua. Kemandiriannya bisa terwujud, tidak lagi merasa khawatir berada jauh pada orang tua. Sebagai orang tua, boleh melarang apa yg anak lakukan. Meskipun bila yg dilakukannya salah. Hal ini dikarenakan anak-anak berada pada masa ingin mencari memahami dunianya tanpa mengenal benar atau salah. Yang wajib kita lakukan merupakan mengarahkan tanpa melarang sehingga anak akan lebih mudah menerima dan mengerti. Melatih kemandirian anak tidak perlu dengan cara 
kasar. Namun dilakukan secara perlahan dan mengikuti kemauan anak itu sendiri. Sehingga kemandirian akan terbentuk tanpa ada rasa terpaksa.

Proses komunikasi yaitu bagaimana komunikator mengungkapkan pesan pada komunikannya, sebagai akibatnya bisa membentuk suatu persamaan makna antara komunikan menggunakan komunikatornya. Proses komunikasi ini bertujuan buat membentuk komunikasi yang efektif (sinkron dengan tujuan komunikasi pada umumnya).

Dari hasil penilitian di ketahui dari 3 narasumber yang telah di wawancarai bahwa interaksi yang di lakukan orang tua dan guru kepada anak di TK Waladun Sholeh. Setiap narasumber memiliki caranya masing-masing untuk melakukan interkasinya kepada anak dalam meningkatkan kemandirian anak itu sendiri.

Proses komunikasi yang terjadi antara orang tua dan anak dalam kehidupan sehari-hari yang orangtua lakukan dengan cara berinteraksi kepada anak secara langsung. Orangtua sering mengajak berbicara atau berdiskusi mengenai kegiatan anak sehari-hari disekolah maupun di rumah. Sebab dengan cara mengajak anak berbicara akan membuat anak merasa lebih dekat dan lebih di perhatikan oleh orangtuanya sendiri. Begitu juga yang di lakukan oleh anak di sekolah, guru melakukan interaksi pendekatan secara langsung kepada anak seperti melakukan kegiatan interkasi bercerita juga menonton film tentang edukasi.

Dengan melalui proses komunikasi, orangtua dan guru mengajari anak dalam membentuk kamandirian. Setiap orangtua memiliki caranya masing-masing untuk meningkatkan kemandirian anak. Dengan menerapkan peraturan yang berikan orangtua kepada anak perlahan anak akan terbiasa melakukan hal-hal kecil seperti membereskan mainan setelah di pakai. Adapun memberikan kebiasaan-kebiasaan kecil kepada anak seperti menyimpan piring yang telah di pakai ke tempat cuci piring. Pelajaran dasar yang anak dapat dari orangtuanya ialah mengikuti apa yang orangtua lakukan sehari-hari. Anak akan lebih mudah mencerna apa yang dia lihat lalu akan meniru perbuatan yang telah di lakukan oleh orangtuanya sendiri. Hal tersebut masuk kedalam penyampaian pesan komunikasi non-verbal.

Setelah adanya proses komunikasi dalam membentuk kemandirian anak ditemukan pengaruh baik atau buruk dari cara penyampaian pesan yang di lakukan orangtua dan guru kepada anak. Hasil dari penyampaian pesan tersebut 
berdampak baik. Anak menjadi pribadi yang mandiri secara perlahan dan terbiasa menerapkan kemandiriannya sehari-hari.

Dengan adanya pengaruh baik dalam penyampaian pesan, tanggapan yang di lakukan orangtua dan guru memberikan apresiasi kepada anak dengan cara memberikan pujian dan terus menyemangati anak dengan kalimat positif. Bila tidak terdapat pengaruh dari cara penyampaian orangtua kepada anak, orangtua terus memberikan dorongan kepada anak supaya anak lebih termotivasi dengan cara memberikan kalimat positif agar mental anak tidak turun untuk melakukan kegiatannya tanpa harus disuruh terlebih dahulu.

Hasil penelitian ini sejalan dengan hasil penelitian Yuli Setiowati (2005) di Yogyakarta mengatakan bahwa salah satu factor yang mempengaruhi perkembangan anak usia dini adalah interaksi yang terjadi antara orangtua dan anak. Penerapan proses komunikasi terhadap proses perkembangan kemandirian anak, Dalam proses komunikasi tersebut, anak akan belajar menerapkan mengenai kemandirian dalam kehidupannya sehari-hari.

Menurut Fisher, hubungan simbolik merupakan teori yg melihat kenyataan sosial yg diciptakan melaui manusia. Sedangkan manusia itu sendiri memiliki kemampuan buat berinteraksi secara simbolik, mempunyai hakikat kebudayaan, saling berhubungan, bermasyarakat, dan mempunyai sebuah pikiran. Setiap bentuk hubungan sosial dimulai dan berakhir menggunakan mempertimbangkan diri manusia. Interaksi anatara orangtua dan anak mempunyai hubungan dengan teori interkasi simbolik, sebab terjadinya proses komunikasi adanya perkembangan diri anak bisa tumbuh karena adanya komunikasi verbal dan non verbal antara orangtua dan anak.

\section{Kesimpulan}

Dari hasil penelitian dan pembahasan dapat disimpulkan bahwa proses komunikasi yang terjalin antara orangtua dan anak efektif. Hal ini disebabkan oleh adanya interaksi yang terjalin antara orangtua dan anak secara terus menerus dalam kegiatan sehari-hari. Faktor keberhasilan proses komunikasi adanya orangtua dan guru memberikan kepercayaan dalam pesan yang disampaikan kepada anak. Keberhasilan pesan yang sampaikan orangtua pada anak . Dengan 
menerapkan peraturan yang berikan orangtua kepada anak perlahan anak akan terbiasa melakukan hal-hal kecil. Keberhasilan penyampaian pesan yang di terima oleh anak karena adanya interaksi yang di lakukan secara perlahan dan terus menerus oleh orang tua seperti memberikan contoh hal-hal kecil yang di lakukan setiap hari dalam kegiatannya sehari-hari.

\section{Daftar Pustaka}

Azeharie, S., \& Khotimah, N. (2015). The Patterns of Interpersonal Communication between Teachers and Students in Children Daycare "Melati" in Bengkulu. Jurnal Pekommas, 18(3), 213-224.

Bala, M. E., Senduk, J., \& Boham, A. (2015). Peran Komunikasi Keluarga dalam Mencegah Perilaku Merokok bagi Remaja di Kelurahan Winangun Kecamatan Malalayang Kota Manado. Jurnal Acta Diurna, IV(3), 1-11. http://ejournal.unsrat.ac.id/index.php/actadiurna/article/viewFile/7498/7045

Putra, K. D., \& Jannah, M. (2013). Perkembangan Kemandirian Anak Usia Dini (Usia 4-6 Tahun) Di Taman Kanakkanak Assalam Surabaya. Character: Jurnal Penelitian Psikologi., 1(3).

Retnowati, Y. (2008). Pola Komunikasi Orangtua Tunggal Dalam Membentuk Kemandirian Anak (Kasus Di Kota Yogyakarta). Jurnal Ilmu Komunikasi UPNYK, 6(3), 199-211. https://doi.org/10.29244/jurnalkmp.6.1.

Santosa, M. A. (1394). Komunikasi Antarpribadi Orangtua Dan Anak Dalam Proses Pengembangan Bakat Dan Pemilihan Karir Anak Dengan Pilihan Profesi Musisi. Ilmu Komunikasi, (5)2(2), 285-299. 